\title{
Liver transplantation: history, outcomes and perspectives
}

\author{
Transplante de fígado: história, resultados e perspectivas
}

\author{
Roberto Ferreira Meirelles Júnior ${ }^{1}$, Paolo Salvalaggio ${ }^{1}$, Marcelo Bruno de Rezende ${ }^{2}$, Andréia Silva Evangelista ${ }^{1}$, \\ Bianca Della Guardia ${ }^{1}$, Celso Eduardo Lourenço Matielo ${ }^{1}$, Douglas Bastos Neves ${ }^{1}$, Fernando Luis Pandullo ${ }^{1}$, \\ Guilherme Eduardo Gonçalves Felga ${ }^{1}$, Jefferson André da Silva Alves ${ }^{1}$, Lilian Amorim Curvelo ${ }^{1}$, \\ Luiz Gustavo Guedes Diaz, Marcela Balbo Rusi ${ }^{1}$, Marcelo de Melo Viveiros ${ }^{2}$, Marcio Dias de Almeida ${ }^{1}$, \\ Pamella Tung Pedroso ${ }^{1}$, Rodrigo Andrey Rocco ${ }^{1}$, Sérgio Paiva Meira Filho ${ }^{1}$
}

\section{ABSTRACT}

In 1958 Francis Moore described the orthotopic liver transplantation technique in dogs. In 1963, Starzl et al. performed the first liver transplantation. In the first five liver transplantations no patient survived more than 23 days. In 1967, stimulated by Calne who used antilymphocytic serum, Starzl began a successful series of liver transplantation. Until 1977, 200 liver transplantations were performed in the world. In that period, technical problems were overcome. Roy Calne, in 1979, used the first time cyclosporine in two patients who had undergone liver transplantation. In 1989, Starzl et al. reported a series of 1,179 consecutives patients who underwent liver transplantation and reported a survival rate between one and five years of $73 \%$ and $64 \%$, respectively. Finally, in 1990, Starzl et al. reported successful use of tacrolimus in patents undergoing liver transplantation and who had rejection despite receiving conventional immunosuppressive treatment. Liver Transplantation Program was initiated at Hospital Israelita Albert Einstein in 1990 and so far over 1,400 transplants have been done. In 2013, 102 deceased donors liver transplantations were performed. The main indications for transplantation were hepatocellular carcinoma (38\%), hepatitis C virus (33.3\%) and alcohol liver cirrhosis (19.6\%). Of these, $36 \%$ of patients who underwent transplantation showed biological MELD score $>30$. Patient and graft survival in the first year was, $82.4 \%$ and $74.8 \%$, respectively. A major challenge in liver transplantation field is the insufficient number of donors compared with the growing demand of transplant candidates. Thus, we emphasize that appropriated donor/ receptor selection, allocation and organ preservation topics should contribute to improve the number and outcomes in liver transplantation.

Keywords: Liver transplantation/history; Liver cirrhosis; Tissue donors; Immunosuppression; Organ preservation; Tissue and organ procurement; Brazil

\section{RESUMO}

Em 1958, Francis Moore descreveu a técnica do transplante de fígado em cães. Em 1963, Starzl e sua equipe realizaram o primeiro transplante de fígado. Nos primeiros cinco transplante de fígado, nenhum paciente sobreviveu mais que 23 dias. Até 1977, aproximadamente 200 transplante de fígado tinham sido realizados no mundo. Neste período, foi estabelecida a solução de problemas técnicos do transplante de fígado. Calne, em 1979, utilizou, pela primeira vez, a ciclosporina em dois pacientes submetidos ao transplante de fígado. Starzl e seus colaboradores relataram, já em 1989, que a sobrevida de 1.179 pacientes submetidos ao transplante de fígado em 1 e 5 anos foi, respectivamente, de 73 e 64\%. Finalmente, em 1990, Starzl relatou o primeiro uso do novo imunossupressor tacrolimo em pacientes de transplante de fígado que apresentavam rejeição mesmo com o tratamento imunossupressor convencional. 0 transplante de fígado iniciou-se no Hospital Israelita Albert Einstein em 1990 e já foram realizados mais de 1.400 transplantes. Em 2013, foram realizados 102 transplantes de fígado de doadores falecidos. As principais indicações para o transplante foram carcinoma hepatocelular (38\%), cirrose hepática secundária ao vírus C $(33,3 \%)$ e cirrose alcoólica (19,6\%). Destes, $36 \%$ dos transplantes apresentavam MELD biológico superior a 30 . As sobrevidas do paciente e do enxerto no primeiro ano foram, respectivamente, 82,4 e $74,8 \%$. Um dos maiores desafios da área do transplante de fígado é o número insuficiente de doadores para uma demanda crescente de candidatos ao procedimento. Dessa forma, destacamos que tópicos relacionados à seleção de doadores/ receptores, alocação e preservação de órgãos devem contribuir para 0 aumento e a melhora dos resultados do transplante de fígado.

Descritores: Transplante de fígado/história; Cirrose hepática; Doadores de tecidos; Imunossupressão; Preservação de órgãos; Obtenção de tecidos e órgãos; Brasil

\footnotetext{
Hospital Israelita Albert Einstein, São Paulo, SP, Brazil.

2 Hospital Santa Marcelina, São Paulo, SP, Brazil.

Corresponding author: Roberto Ferreira Meirelles Júnior - Avenida Albert Einstein, 627, Bloco A1, consultório 112 - Morumbi - Zip code: $05652-900$ - São Paulo, SP, Brazil - Phone: (11) 2151-9222 E-mail: roberto.meirelles@einstein.br

Received on: May 5, 2014 - Accepted on: Feb 8, 2015

DOI: 10.1590/\$1679-45082015RW3164
} 


\section{INTRODUCTION}

Liver transplantation is the treatment of choice for patients with cirrhosis, decompensated disease, acute liver failure and hepatocellular cancer within Milan criteria. $^{(1)}$

This study briefly reviews history, and shows recent results of liver transplantation in Brazil and around the world, as well as controversial topics and perceptives in this subject.

\section{HISTORY OF LIVER TRANSPLANTATION}

In 1955, Welch was the first to describe scientifically the liver transplantation as a treatment. In that time, he proposed an ectopic liver transplantation in abdominal cavity. ${ }^{(2)}$ In 1958, Francis Moore described the first orthotopic liver transplantation in dogs. ${ }^{(3)}$

In March 1st 1963, Starzl et al. did the first liver transplantation in the world. The patient was an 3 -year-old boy with biliary atresia who underwent liver transplantation, however, he died during the surgery because of coagulation disorder and uncontrolled bleeding. ${ }^{(4)}$ First, all liver transplant patients received immunosuprresion proposed for kidney transplantation, i.e., azathioprine and corticoids. Hence, results were discouraging. No patient have survived more than 23 days in the first 5 liver transplantation performed.(4) Ischemia-reperfusion injury and rejection inevitably progressed to liver failure or sepsis.

Discoraging and recognizing the large difficults posed for liver transplantation, Starzl progressively developed procedures and principles that guide liver transplantation to date. In 1967, stimulated by Calne to use anti-thymocyte globulin, Starzl successfully performed several liver transplantations at the University of Colorado. The first case was a patient with advanced hepatocelular cancer who survived more than 1 year with preserved liver function and died due to the disease recurrence. ${ }^{(5)}$

Because of the relative success and improve of initial survival, $70 \%$ of deaths were common in most of liver transplantation services. The non-selective immunosuppression scheme associated with the surgical complexity of liver transplantation lead patients to become extremely vulnerable to infections.

Infection complications and chronic rejection in liver transplantation were the main cause of early and late deaths, respectively. Hence, better immunosuppresses and anti-infection agents. Until 1997, roughly 200 transplantations have been done in the world. In this period, technical problems of biliary reconstruction, intraoperative coagulopathy treatment and surgical technical of donor were stated. ${ }^{(6)}$ In the following 15 years only the University of Colorado and Cambridge University conducted experimental clinical studies in liver transplantation. ${ }^{(7)}$

In 1979, Calne used for the first time the cyclosporine in two patients who had undergone liver transplantation launching a new step in history of liver transplantation. ${ }^{(8)}$ In 1983, the National Institutes of Health, after evaluate the result of 531 cases, approved liver transplantation as a valid therapy for treament of end-stage liver diseases.

In 1989, Starzl et al. reported survival of 1,179 patients submitted to liver transplantation from 1 to 5 years after the procedure ( $73 \%$ and $64 \%$, respectively). These results corresponded to double the survival of patients who used azathioprine and corticoids. ${ }^{(9)}$

Finally, in 1990, Starzl et al. reported the first use of the new tacrolimus as imunosupressant agent in patients submitted to liver transplantation who suffered a rejection even using conventional immunosuppressive treatment. The success of cyclosporine conversion by tracrolimus in these patients and by showing it safety, new clinical studies were conducted using tacrolimus as the main immunosuppressor in liver transplantation. ${ }^{(10-12)}$

Currently, more than 40 years from the first liver transplantation, more than $10.000,00$ liver transplantations have been performed in the world so far. Liver transplant patients' survival within the first year is roughly $80 \%$ to $90 \%$. A progressive improve in results, surgical problems, rejection treatment and untreated sepsis control were resolved. ${ }^{(10)}$ However, the number of patients in waiting list for liver transplantation has progressively increased compared with the number of deceased donors. However, there is the need of better access for patients to transplantation center, progresses in organization and improvements in transplantation system, filter in indications and better use of donations made.

\section{GENERAL OVERVIEW OF LIVER TRANSPLANTATION IN BRAZIL}

In 1968, Machado et al. performed the first liver transplantation at Hospital das Clínicas da Faculdade de Medicina da Universidade de São Paulo (HC-FMUSP). Their patient had survived for 7 days, but he developed infection and acute allograft rejection. ${ }^{(13)}$ In 1969 and 1971 other two patients were submitted to liver transplantation and survival was, respectively, 18 and 30 days. In 1985 Silvano Raia restart liver transplantation in Brazil at HC-FMUSP and 1988, Raia et al. performed the first living donor transplation in the world. ${ }^{(14)}$

In the last decades an expressive increase in number of transplantation teams in Brazil have been seen. These 
teams are more concentrated in South and Southeast region. The Brazil Public health System is responsible for more than $95 \%$ of liver transplantations done in the country, and it provides universal access to treatment, and even immunosuppressant agents for patients. Brazil has become the world's largest public system of transplantation and the third in world when it comes to liver transplantation. The population's awareness about organs and tissues transplantation and identification of potential donor by health professional have been improved so far. The number of donations in Brazil has reached an unprecedented number of 13.2 per million inhabitants. In the last 2 years, Brazil Federal Government has successfully increase and promote the decentralization of transplantation teams in the country. Such actions must continue to increase the transplants in Brazil and place the country as world leader in liver transplantation.

\section{LIVER TRANSPLANTATION AT HOSPITAL ISRAELITA ALBERT EINSTEIN}

Liver transplantation at Hospital Israelita Albert Einstein (HIAE) began in 1990. So far, the hospital liver transplantation program has done more than 1,400 transplants. Of these, $95 \%$ were patients referred from Brazil Public Health System. These patients have complete access to the hospital's infrastructure, resources and medical team without any cost.

In 2013, a total of 102 adult deceased donor liver transplantations were performed. Main reasons for transplantation were hepatocellular cancer (38\%), liver cirrhosis due to hepatitis C virus (33.3\%), and alcoholic cirrhosis (19.6\%). Other indications were cryptogenic cirrhosis (9.8\%) fatty liver $(19.6 \%)$ and acute liver failure $(5.8 \%)$. Of these, $36 \%$ of transplants had MELD score $>30$. Indexes of primary allograft non-function, hepatic artery thrombosis and early mortality were $7.8 \%$, $1.9 \%$ and $9.8 \%$, respectively. Survival of patients, first, third and fifth allografts are presented in table 1 and 2. Figures 1 and 2 describe survival curves of patient and allograft compared with liver transplantation services in São Paulo State.

Table 1. Patients survival in first, third and fifth year after liver transplantation from January 1 st 2006 and December 31st 2013

\begin{tabular}{lccc}
\hline Post-transplantation period & $\begin{array}{c}\text { São Paulo State } \\
(\mathbf{\%})\end{array}$ & $\begin{array}{c}\text { HIAE } \\
(\mathbf{\%})\end{array}$ & $\begin{array}{c}\text { UNOS } \\
(\mathbf{\%})\end{array}$ \\
\hline 1 year & 69.4 & 82.4 & 89.7 \\
3 years & 65.1 & 77.3 & 81 \\
5 years & 62.6 & 74.3 & 74.3 \\
\hline
\end{tabular}

Source: Secretaria de Estado da Saúde de São Paulo and UNOS.

HIAE: Hospital Israelita Albert Einstein; UNOS: United National Organ Sharing.
Table 2. Allografts survival in first, third and fifth year after liver transplantation from January 1st 2006 and December 31st 2013

\begin{tabular}{lccc}
\hline Post-transplantation period & $\begin{array}{c}\text { São Paulo State } \\
(\mathbf{\%})\end{array}$ & $\begin{array}{c}\text { HIAE } \\
(\mathbf{\%})\end{array}$ & $\begin{array}{c}\text { UNOS } \\
\mathbf{( \% )}\end{array}$ \\
\hline 1 year & 65.3 & 74.8 & 85.2 \\
3 years & 60.3 & 68.2 & 75.1 \\
5 years & 57.4 & 63.4 & 68.5 \\
\hline
\end{tabular}

Sources: Secretaria de Estado da Saúde de São Paulo and UNOS

HIAE: Hospital Israelita Albert Einstein; UNOS: United National Organ Sharing.
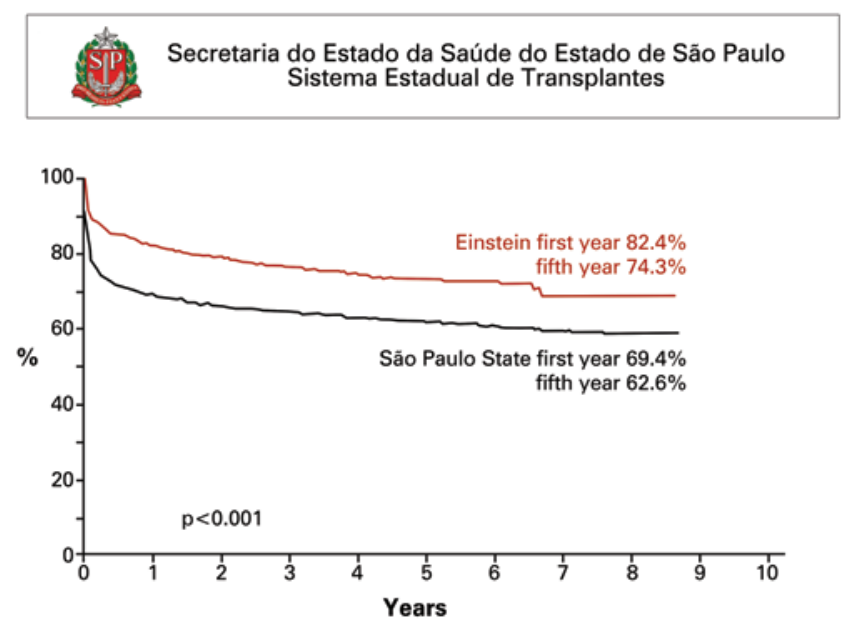

Figure 1. Actuarial survival curve. Kaplan-Meier of patients who underwent liver transplantation at Hospital Israelita Albert Einstein $(n=748)$ and at other liver transplantation services in São Paulo State $(n=3.738)$ from January 2006 and December 2013
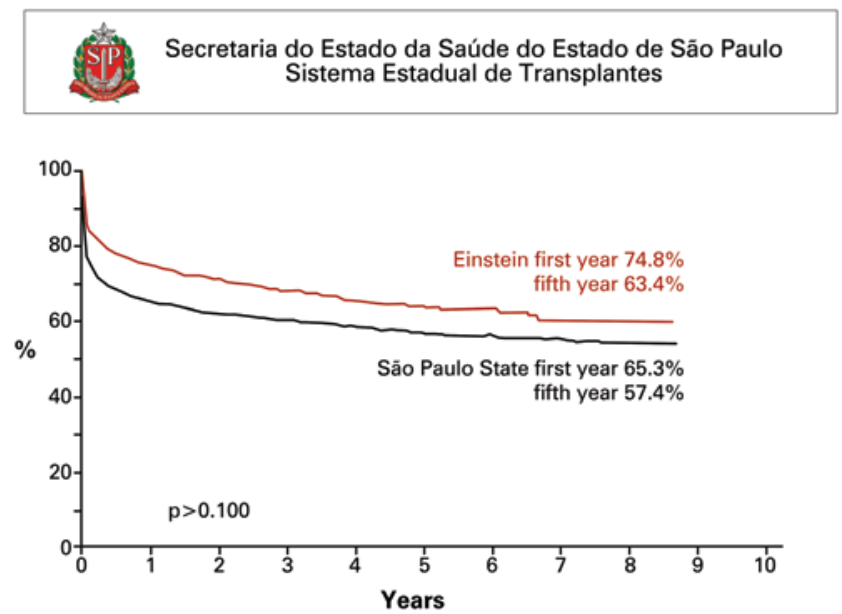

Figure 2. Actuarial survival curve. Kaplan-Meier of patients who received hepatic allografts at Hospital Israelita Albert Einstein $(n=858)$ and at other liver transplantation services in São Paulo State $(n=4.075)$ from January 2006 and December 2013

\section{CURRENT INTERESTING TOPICS AND PERSPECTIVES}

One of the biggest challenges of liver transplantation area is the insufficient number of donors compared with the growing demand of transplant candidates. 
Therefore, we highlight the related-topics to donor/ recipient selection, allocation and organ preservation must contribute for the improvement of results in liver transplantation.

The use of xenotransplantation, mainly by the use of genetically modified pigs as well as bioengineering by creation of synthetic liver in the laboratory can change dramatically the allografts paucity. ${ }^{(15)}$ However, until we reach this next level, news strategies must focus in provision of the maximal use of hepatic allografts in Brazil. Perhaps, the use of allografts, otherwise discarded, can be possible by using pharmacological or mechanical strategies. Among these strategies, we must emphasize the recent development of perfusion devices that seem to modulate very interesting the ischemicreperfusion injury. ${ }^{(16,17)}$

The possible use of living donors must be considered. The indication and modern techniques arising have contributed for this alternative use and consequently increase of the number of patients' benefit by transplantation.

In São Paulo State, we have observed that scarcity of organs forces transplantation services to treat extremely ill patients. The discussion of uselessness, limits for indications in this scenario and adjusts for MELD score system must emphasize during scientific meetings. ${ }^{(18)}$

Finally, we used Milan criteria for patients with hepatocellular cancer in order to provide them the chance to perform the transplantation. However, several evidences exist that some patients, which overcome Milan criteria, can be also benefit by transplantation. ${ }^{(19,20)}$ In the future, new markers that will help to better select such patients, mainly with the use of genetic sequencing, must be developed. Finally, the discussion of allocation criteria for this population will continue to be a present topic in our scientific meetings.

\section{CONCLUSION}

Despite the progressive improve in results because of the evolution of surgical technique, immunosuppression, treatment of rejection and infection, the challenging of treating patients who need liver transplantation remains as the single therapeutic option. The continuous practice of excellence in the treatment and the constant search to improve results must guide the future in liver transplantation.

\section{REFERENCES}

1. Fox AN, Brown RS Jr. Is the patient a candidate for liver transplantation? Clin Liver Dis. 2012;16(2):435-48. Review.

2. Welch CS. [Liver graft]. Maroc Medical. 1955;34(359):514-5. French.

3. Moore FD, Smith LL, Burnap TK, Dallenbach FD, Dammin GJ, Gruber UF, et al. One-stage homotransplantation of the liver following total hepatectomy in dogs. Transplantation Bulletin. 1959;6(1):103-7.

4. Starzl TE, Marchioro TL, Vonkaulla KN, Hermann G, Brittain RS, Waddell WR. Homotransplantation of the liver in humans. Surg Gynecol Obstet. 1963;117:659-76.

5. Starzl TE, GrothCG, Brettschneider L, Penn I, Fulginiti VA, Moon JB, etal. Orthotopic homotransplantation of the human liver. Ann Surg. 1968;168(3):392-415.

6. Starzl TE, Putnam CW, Koep LJ. Current status of liver transplantation. South Medical J. 1977;70(4):389-90.

7. Starzl TE, Iwatsuki S, Klintmalm G, Schröter GP, Weil R 3rd, Koep LJ, et al. Liver transplantation, 1980, with particular reference to cyclosporin-A. Transplant Proc. 1981;13(1 Pt 1):281-5.

8. Calne RY, Rolles K, White DJ, Thiru S, Evans DB, McMaster P, et al. Cyclosporin A initially as the only immunosuppressant in 34 recipients of cadaveric organs: 32 kidneys, 2 pancreases, and 2 livers. Lancet. 1979;2(8151):1033-6.

9. Starzl TE, Todo S, Tzakis AG, Gordon RD, Makowka L, Stieber A, et al. Liver transplantation: an unfinished product. Transplant Proc. 1989;21 (1 Pt 2):2197-200.

10. Fung JJ, Todo S, Jain A, McCauley J, Alessiani M, Scotti C, et al. Conversion from cyclosporine to FK 506 in liver allograft recipients with cyclosporinerelated complications. Transplant Proc. 1990;22(1):6-12

11. Fung JJ, Todo S, Tzakis A, Alessiani M, Abu-Elmagd K, Jain A, et al. Current status of FK 506 in liver transplantation. Transplant Proc. 1991;23(3):1902-5.

12. Todo S, Fung JJ, Demetris AJ, Jain A, Venkataramanan R, Starzl TE. Early trials with FK 506 as primary treatment in liver transplantation. Transplant Proc. 1990;22(1):13-6.

13. Bacchella T, Machado MC. The first clinical liver transplantation of Brazil revisited. Transplant Proc. 2004;36(4):929-30.

14. Raia S, Nery JR, Mies S. Liver transplantation from live donors. Lancet. 1989;2(8661):497.

15. Cooper DK, Hara H, Ezzelarab M, Bottino R, Trucco M, Phelps C, et al. The potential of genetically-engineered pigs in providing an alternative source of organs and cells for transplantation. J Biome Res. 2013;27(4):249-53.

16. op den Dries S, Karimian N, Sutton ME, Westerkamp AC, Nijsten MW, Gouw $A S$, et al. Ex vivo normothermic machine perfusion and viability testing of discarded human donor livers. Am J Transplant. 2013;13(5):1327-35.

17. Henry SD, Nachber E, Tulipan J, Stone J, Bae C, Reznik L, et al. Hypothermic machine preservation reduces molecular markers of ischemia/reperfusion injury in human liver transplantation. Am J Transplant. 2012;12(9):2477-86.

18. Salvalaggio P, Afonso RC, Pereira LA, Ferraz-Neto BH. The MELD system and liver transplant waiting-list mortality in developing countries: lessons learned from Sao Paulo, Brazil. Einstein. 2012;10(3):278-85. English.

19. Mazzaferro V, Bhoori S, Sposito C, Bongini M, Langer M, Miceli R, et al. Milan criteria in liver transplantation for hepatocellular carcinoma: an evidence-based analysis of 15 years of experience. Liver Transpl. 2011;17 Suppl 2:S44-57. Review.

20. Yao FY. Liver transplantation for hepatocellular carcinoma: beyond the Milan criteria. Am J Transplant. 2008;8(10):1982-9. Review. 